\title{
The Impact of Scientific Approach and What-If-Not Strategy Utilization towards Student's Mathematical Problem Posing Ability
}

\author{
Harry Dwi Putra \\ IKIP Siliwangi, Cimahi, Indonesia, harrydp@ikipsiliwangi.ac.id
}

\section{Tatang Herman}

Universitas Pendidikan Indonesia, Bandung, Indonesia,tatangherman@upi.edu

\section{Utari Sumarmo}

Universitas Pendidikan Indonesia, Bandung, Indonesia, utari.sumarmo@gmail.com

\begin{abstract}
Activities that play a significant role in mathematical thinking and problemsolving are mathematical problem posing. Scientific Approach with What-If-Not strategy (SA-WIN) is innovative learning that can improve the Mathematical Problem Posing Ability (MPPA) of students rather than Conventional Teaching (CT). This study aims to analyze the improvement of students' MPPA between those using PS-WIN and CT through N-gain test and t-test, student perception on PS-WIN and student difficulties in completing MPPA tests through descriptive analysis, and interactions between PMA and learning approaches to improve MPPA trough two-way ANOVA. The study was a pretest-posttest control group design. The sample of this study was 68 students of XI grade in one of SMAN in Cimahi, Indonesia. Instruments of this study were an MPPA test that has been validated through trials, a Prior Mathematical Ability (PMA) test and a student's perception scale on SA-WIN which had been validated by two experts. This study found that the improvement of students' MPPA using SA-WIN was better than students who used conventional teaching. Student MPPA scores are at a medium level. Most students who use conventional teaching have difficulties in solving problems in the MPPA test. Learning using SA-WIN encourages students to be active in asking questions, discussing, and solving MPP problems. Students give a positive perception of SA-WIN. There was no interaction between PMA and the teaching approach to improve the MPPA of students.
\end{abstract}

Keywords: mathematical problem posing, scientific approach, what-if-not strategy, conventional teaching, student's perception scale

Citation: Putra, H. D., Herman, T., \& Sumarmo, U. (2020). The Impact of Scientific Approach and What-If-Not Strategy Utilization towards Student's Mathematical Problem Posing Ability. International Journal of Instruction, 13(1), 669-684. https://doi.org/10.29333/iji.2020.13143a 


\section{INTRODUCTION}

Up to now, many mathematics experts and teachers believed that Mathematical Problem Solving Ability (MPSA) should be improved on high school students caused of MPSA was attached on the goal of mathematics teaching and learning (Mathematics Curriculum of Indonesia in 2013). Even, Branca (1980) stressed that MPSA was a basic ability and the hart of mathematics teaching. Likewise, MPSA helped the student to think analytically, critically, and creatively, and to improve other mathematics abilities. Mathematics curriculum did not take sufficient attention yet on developing Mathematical Problem Posing Ability (MPPA). MPPA was an old matter in mathematics teaching. Singer, Ellerton, \& Cai (2013) proposed that the new thing about MPP was awareness of some experts toward the importance of MPP content in mathematics teaching and learning.

The importance of MPP content was in line with experts' opinion such as (a) MPP was essential content in mathematics, in the nature of mathematical thinking, and mathematical problem solving (Bonotto, 2013); (b) To help student to solve mathematics problem well, posed student some directed questions on solving problem, motivate student to pose his own question, give meaningful hint and not the steps of solving problem (Polya, 1985); (c) Improvement of mathematics ability needed creative mathematical imagination that could be enhanced by arousing new question, creating new possibility, and viewing old question from new point of view (Ellerton \& Clarkson, 1996); (d) During mathematics learning, student should be trained to pose question or problem and to broaden problem from an old one and to solve it (Vinet \& Zhedanov, 2010).

Polya (1985) posed that teacher's role was not only to deliver mathematics content, but the most essential things were position teacher is as a student, appreciate student's thinking, and motivate the student to learn better. Conventional teaching refers to teaching methods that involve teachers and students interacting face to face in class. The teacher begins discussions in the classroom and focuses exclusively on knowing the content in textbooks and notes. Students receive information passively and repeat information through memorization (McCarthy \& Anderson, 2004). Many teachers still teach their students in the same way as to how they were taught by their teachers, not much progress in terms of teaching perspectives (Anglin \& Anglin, 2008).

Teaching-learning approach which in line with the suggestion of Curriculum in Indonesia and Polya's opinion among others was the scientific approach. Sudarwan (2013) and Hosnan (2014) proposed that scientific approach was an approach for acquiring knowledge through some steps such as: observing, questioning, collaborating, experimenting, associating, and presenting. To relate the traits of MPPA which containing creative ability component and the activities in each phase of the SA approach, it was predicted the lesson would be more successful when SA was completed with what-if-not strategy. The what-if-not strategy facilitated student to compile new problem from the previous problem by modifying condition of the old problem, then student improved his creative mathematics ability and considered more in-depth the meaning of the problem (Silver, 2013). 
Those aforementioned arguments motivated researchers to carry out a study having a goal to analyze the role of SA-WIN and Prior Mathematical Ability (PMA) on student's MPPA and posed research questions: Is the improvement of students' MPPA who get learning with SA-WIN better than those who get Conventional Teaching (CT) based on each PMA level? What difficulties do students experience in completing MPPA assignments? What do students think about PS-WIN? Are there interactions between PMA and learning approaches to improve MPPA?

\section{METHOD}

\section{Research Design}

This study was a pretest-posttest control group design (Creswell, 2009). Subjects were 68 students grouped into two classes. Students in the experimental class were 34 and in the control class were 34. The experimental class obtained Scientific Approach with What-If-Not strategy (SA-WIN) and the control class gained CT. In each class, students are grouped based on high, medium, and low abilities. Research design according to as follows:

$$
\begin{array}{llll}
\text { Experimental (E) } & : \mathrm{O}_{1} \mathrm{E} & \mathrm{O}_{2} \\
\text { Control (C) } & : & \mathrm{O}_{3} \mathrm{C} & \mathrm{O}_{4}
\end{array}
$$

Information:
$\mathrm{O}_{1} \& \mathrm{O}_{2}=$ Pretest and posttest in the experimental class
$\mathrm{O}_{3} \& \mathrm{O}_{4}=$ Pretest and posttest in the control class
$\mathrm{E} \quad=$ Learning using SA-WIN in the experimental class
$\mathrm{C}=$ Conventional teaching in the control class

The items about the pretest and posttest in the experimental and control classes were the same. The research procedure is shown in Figure 1 below:

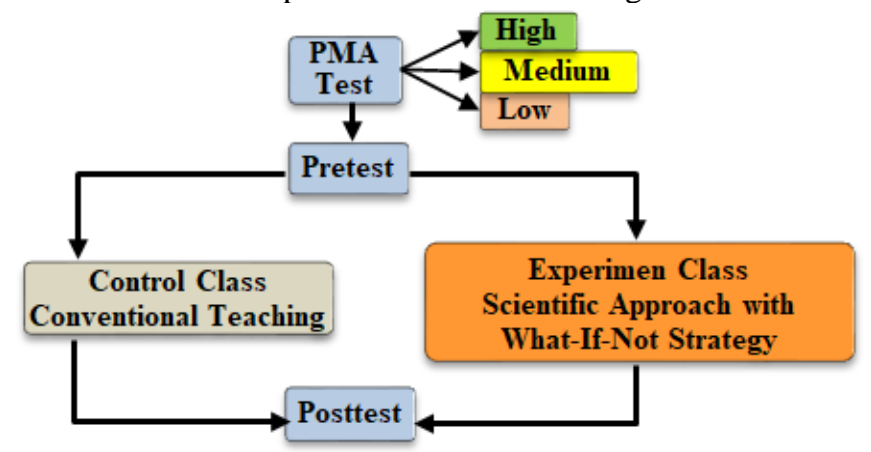

Figure 1

Research Procedure

Figure 1 shows that before conducting the pretest, students in the experimental and control classes were given a PMA test. The aim is to group students' abilities with high, 
medium, and low criteria. The number of students based on ability grouping is shown in Table 1 below:

Table 1

Grouping Students based on the PMA Test

\begin{tabular}{lll}
\hline \multirow{2}{*}{ PMA } & \multicolumn{2}{c}{ The number of students } \\
\cline { 2 - 3 } & Experiment & Control \\
\hline High & 7 & 6 \\
Medium & 17 & 17 \\
Low & 10 & 11 \\
Total & 34 & 34 \\
\hline
\end{tabular}

Table 1 shows students with high-PMA more than one person in the experimental class than students in the control class. Students with medium-PMA are in the experimental class as much as students in the control class. Students with low-PMA more than one person in the control class than students in the experimental class.

After obtaining student grouping data based on the PMA test, then students are given a pretest to find out the student's initial score before obtaining learning. Students in the experimental class gained learning with Scientific Approach with What-If-Not Strategy (SA-WIN), while students in the control class obtained learning using Conventional Teaching (CV). If all the material about the rules of enumeration has been studied by students, the last meeting of learning, they are given a posttest. Posttest scores are useful for analyzing the achievement and improvement of students' Mathematical Problem Posing Ability (MPPA).

\section{Participants}

The study was conducted on IX grade students in one of SMAN in Cimahi, Indonesia. A total of 8 classes of IX grade students have randomly selected 2 classes. The sample of this study was 68 students consisting of 34 students in the experimental class and 34 students in the control class. Experimental class students get learning with SA-WIN, while control class students get learning with $\mathrm{CT}$.

\section{Instruments}

The study involved a multiple-choice PMA test, an essay MPPA test, and scale of student perception of SA-WIN. The PMA test consisted of 20 items, the MPPA test consisted of 5 items, and the perception of SA-WIN consisted of 40 statements in Likert's model.

MPPA test is carried out the validity test, reliability test, differentiation test, and difficulty index test. Test the validity of the test items using the following formula (Arikunto, 2013).

$$
r=\frac{N \sum X Y-\sum X \sum Y}{\sqrt{\left[\left(N \sum X^{2}\right)\right]\left[N \sum Y^{2}-\left(\sum y\right)^{2}\right]}}
$$

Information:

$\mathrm{r} \quad=$ Coefficient of test validity 
$\mathrm{N}=$ The number of test-takers

$\mathrm{X}=$ Score of each item

$\mathrm{Y} \quad=$ The total score of each item

The MPPA reliability test uses the following formula (Hendriana \& Sumarmo, 2014).

$r=\left(\frac{k}{k-1}\right)\left(\frac{s_{t}^{2}-\sum s_{i}^{2}}{s_{t}^{2}}\right)$

Information:

$r=$ Reliability coefficient of the test

$k=$ Many items

$s_{1}=$ Standard deviation of the i-th test item

$s_{t}=$ Standard deviation of all test items

The validity and reliability criteria of the MPPA test (Arikunto, 2013) are shown in Table 2 below:

Table 2

The Validity and Reliability Criteria of the MPPA Test

\begin{tabular}{ll}
\hline Interval & Criteria \\
\hline $0,8<r \leq 1,0$ & Very high \\
$0,6<r \leq 0,8$ & High \\
$0,4<r \leq 0,6$ & Medium \\
$0,2<r \leq 0,4$ & Low \\
$0,0<r \leq 0,2$ & Very low \\
\hline
\end{tabular}

The Distinguishing Power (DP) of the MPPA test uses the following formula (Hendriana \& Sumarmo, 2014).

$D P=\frac{S_{A}-S_{B}}{J_{A}}$

Information:

$D P=$ Distinguishing Power

$S_{A}=$ The sum of the top group scores on test items (30\% of many participants)

$S_{B}=$ The sum of the upper group scores on test items (30\% of many participants)

$J_{A}=$ Ideal score of test items

The criteria for distinguishing power of the MPPA tests (Arikunto, 2013) are shown in Table 3 below:

Table 3

The Criteria for Distinguishing Power (DP) of the MPPA Test

\begin{tabular}{ll}
\hline Interval & Criteria \\
\hline $0,7 \leq D P<1,0$ & Very good \\
$0,4 \leq D P<0,7$ & Good \\
$0,2 \leq D P<0,6$ & Pretty good \\
$0,0 \leq D P<0,2$ & Very bad \\
\hline
\end{tabular}


Difficulty Index (DI) of the MPPA test uses the following formula (Hendriana \& Sumarmo, 2014).

$D I=\frac{S_{A}+S_{B}}{2 J_{A}}$

Information:

$D I=$ Difficulty Index

$S_{A}=$ The sum of the top group scores on test items (30\% of many participants)

$S_{B}=$ The sum of the upper group scores on test items (30\% of many participants)

$J_{A}=$ Ideal score of test items

The criteria for difficulty index of the MPPA tests (Hendriana \& Sumarmo, 2014) are shown in Table 4 belowTable 2:

Table 4

The Criteria for Difficulty Index (DI) of the MPPA Tests

\begin{tabular}{ll}
\hline Interval & Criteria \\
\hline $0,9 \leq D I<1,0$ & Very easy \\
$0,6 \leq D I<0,9$ & Easy \\
$0,4 \leq D I<0,6$ & Medium \\
$0,2 \leq D I<0,4$ & Difficult \\
$0,0 \leq D I<0,2$ & Very difficult \\
\hline
\end{tabular}

Characteristics of MPPA test is based on validity, reliability, distinguishing power, and difficulty index as follow: validity was $\mathrm{r}=0.73$ are at intervals $0,6 \leq r<0,8$ have high criteria; reliability test was $\mathrm{r}=0.84$ are at interval $0,8<r \leq 1,0$ have very high criteria; Discriminate Power (DP) were 0.62 are at interval $0,4 \leq D P<0,7$ have good criteria, and Difficulty Index (DI) were 0.41 are at interval $0,4 \leq D I<0,6$ have medium criteria. The result of research from Putra (2017) states that valid instruments can improve the ability of MPPA students with medium criteria. The PMA test and the scale of student perception of SA-WIN were validated by two lecturers who were experts in the field of mathematics education. The opinion of the two experts stated that the PMA test and scale of student perception of SA-WIN was valid.

The sample from the MPPA test item and the perception scale of the SA-WIN are shown as follows:

\section{Sample item of MPPA test}

There are five men and four women to form a line so that women occupy an even position. How many possibilities is that line? Arrange two new questions from the question above. Then, select one new question and finish accompanied by an explanation of the formula used!

2. Sample item of perception scale of SA-WIN

Note:

SA: Strongly Agree, A: Agree, DA: Disagree, and SDA: Strongly Disagree. 
Table 5

Sample Item of Perception Scale of SA-WIN

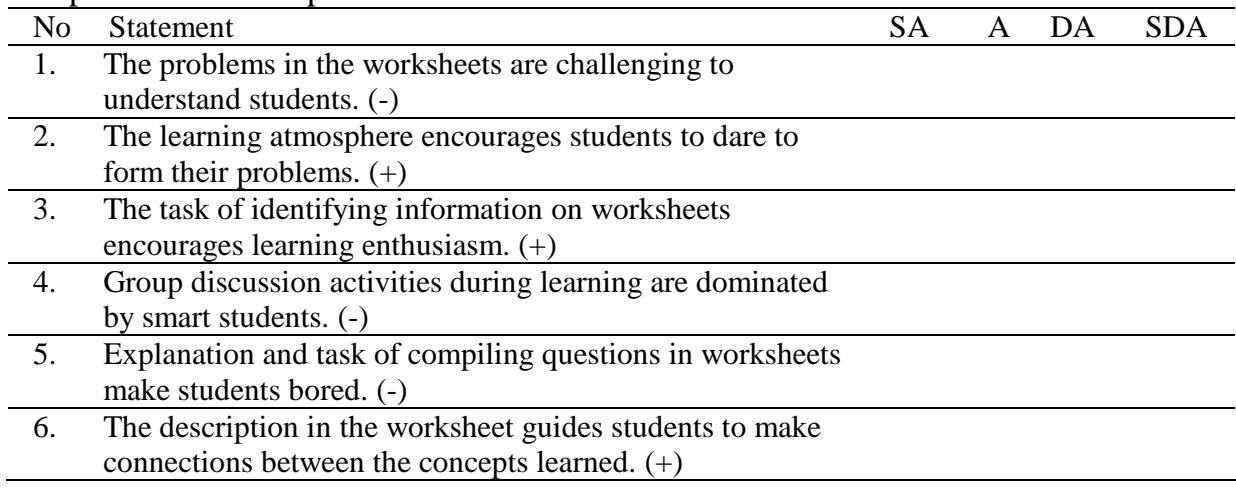

\section{Data Analysis}

The data of the MPPA test were used to determine groups of students with high, medium, and low abilities. The ideal score of the PMA test was 20. Criteria for grouping students' abilities are shown in Table 6 below:

Table 6

Criteria for Grouping Students in the PMA Test

\begin{tabular}{ll}
\hline Score $(x)$ & Criteria \\
\hline$x>75 \%$ of ideal score & High \\
$65 \%$ of ideal score $\leq x \leq 75 \%$ of ideal score & Medium \\
$x<65 \%$ of ideal score & Low \\
\hline
\end{tabular}

The pretest and posttest data on the MPPA test were assessed using the scoring rubric in Table 7 below:

Table 7

The Scoring Rubric of MPPA Test

\begin{tabular}{ll}
\hline Response & Score \\
\hline There is no response/irrational response & 0 \\
Arrange 1 MPPA correctly & 1 \\
Arrange 2 MPPA correctly & 2 \\
Arrange 2 MPPA correctly and answer 1 MPPA correctly & 3 \\
\hline
\end{tabular}

MPPA test has an ideal score of 48. The improvement of students' MPPA was obtained using the N-gain (Hake, 1999) as follows:

$\mathrm{N}$-gain $=\frac{\text { posttest-pretest }}{\text { ideal score-pretest }}$

The criteria improvement of MPPA based on N-gain are shown in Table 8 below: 
Table 8

$\mathrm{N}$-gain Criteria for MPPA

\begin{tabular}{ll}
\hline $\mathrm{N}$-gain $(\mathrm{g})$ & Criteria \\
\hline $\mathrm{g}>0,7$ & High \\
$0,3<\mathrm{g} \leq 0,7$ & Medium \\
$\mathrm{g} \leq 0,3$ & Low \\
\hline
\end{tabular}

Analysis of interaction between PMA and learning approaches to improve the MPPA of students using two-way ANOVA in SPSS Statistics. Based on the output of the SPSS Statistics, if the significance (sig.) $\geq 0.05$ indicates that there is no interaction between PMA and learning approaches to improve the MPPA of students.

\section{FINDINGS}

Description of student's MPPA was shown in Table 9 below:

Table 9

Description of MPPA of Students in Both Teaching Approaches

\begin{tabular}{|c|c|c|c|c|c|c|c|c|c|}
\hline \multirow[b]{2}{*}{ PMA } & & \multicolumn{4}{|c|}{ SA-WIN } & \multicolumn{4}{|l|}{$\mathrm{CT}$} \\
\hline & & Pretest & Posttest & $\mathrm{N}$-gain & $\mathrm{n}$ & Pretest & Posttest & $\begin{array}{l}\mathrm{N}- \\
\text { gain }\end{array}$ & $\mathrm{n}$ \\
\hline \multirow{3}{*}{ High } & $\overline{\bar{x}}$ & 13.71 & 33.71 & \multirow{2}{*}{0.59} & \multirow{3}{*}{7} & 14.83 & 26.33 & \multirow{2}{*}{0.34} & \multirow{3}{*}{6} \\
\hline & $\%$ & 28.57 & 70.24 & & & 30.90 & 54.86 & & \\
\hline & $\mathrm{s}$ & 3.15 & 4.99 & 0.13 & & 3.25 & 2.34 & 0.07 & \\
\hline \multirow{3}{*}{ Medium } & $\overline{\mathrm{x}}$ & 10.82 & 24.71 & \multirow{2}{*}{0.37} & \multirow{3}{*}{17} & 10.59 & 18.12 & \multirow{2}{*}{0.20} & \multirow{3}{*}{17} \\
\hline & $\%$ & 22.55 & 51.47 & & & 22.06 & 37.75 & & \\
\hline & $\mathrm{s}$ & 2.92 & 4.67 & 0.16 & & 2.21 & 3.04 & 0.06 & \\
\hline \multirow{3}{*}{ Low } & $\overline{\mathrm{x}}$ & 6.40 & 19.40 & \multirow{2}{*}{0.31} & \multirow{3}{*}{10} & 6.91 & 13.45 & \multirow{2}{*}{0.16} & \multirow{3}{*}{11} \\
\hline & $\%$ & 13.33 & 40.42 & & & 14.39 & 28.03 & & \\
\hline & $\mathrm{s}$ & 2.95 & 5.15 & 0.11 & & 2.07 & 3.36 & 0.08 & \\
\hline \multirow{3}{*}{ Total } & $\overline{\mathrm{x}}$ & 10.12 & 24.91 & \multirow{2}{*}{0.40} & \multirow{3}{*}{34} & 10.15 & 18.06 & \multirow{2}{*}{0.21} & \multirow{3}{*}{34} \\
\hline & $\%$ & 21.08 & 51.90 & & & 21.14 & 37.62 & & \\
\hline & $\mathrm{s}$ & 3.94 & 6.92 & 0.15 & & 3.59 & 5.31 & 0.09 & \\
\hline
\end{tabular}

Based on Table 9, in the pretest, it found that there was no difference in student's MPPA level in both teaching approaches and the level was at a very low. Nevertheless, after the learning process, on MPPA and its gain (N-gain), students getting treatment with SAWIN attained a better level than the level of students taught by conventional teaching. However, both levels were at medium. Then, when we observed student's level of MPPA in each level of PMA in both teaching approaches, in posttest the higher level of student's PMA (low, medium, high) it also found the higher student's level of MPPA as well (in both teaching approaches were found $(\overline{\mathrm{x}} \mathrm{L}<\overline{\mathrm{x}} \mathrm{M}<\overline{\mathrm{x}} \mathrm{H})$. It meant that PMA took a good role in obtaining student's MPPA.

In each level of PMA (low, medium, high), in posttest of MPPA, the study found that $\overline{\mathrm{X}}$ SA-WIN $>\overline{\mathrm{X}}_{{ }_{\mathrm{CT}}}$. It meant that SA-WIN took a better role than conventional teaching on attaining student's MPPA. Based on Table 9, it found that student's MPPA of the low level of PMA in SA-WIN (19.40) was higher than student's MPPA with a medium level of PMA in conventional teaching (18.12). But, student's MPPA with a medium level of PMA in SA-WIN (24.17) was lower than the student's MPPA with a high level of PMA in conventional teaching (26.33). These findings illustrated that SA-WIN and PMA had 
almost the same level of role in attaining student's MPPA. Different findings were detected on the N-gain of student's MPPA. Those findings pointed out that level of PMA and SA-WIN conferred a bigger role than PMA on attaining N-gain of MPPA. The ideal score of MPPA is 48. In entire students and in each level of PMA, the study found that in both teaching approaches, student's level of MPPA was still at medium.

Table 10

Testing Hypothesis of Mean Difference of MPPA, N-gain (g) MPPA on Both Teaching Approaches

\begin{tabular}{|c|c|c|c|c|c|c|c|}
\hline Variables & $\begin{array}{l}\text { Teaching } \\
\text { Approach }\end{array}$ & $\bar{x}$ & SD & $\mathrm{n}$ & $\begin{array}{l}\text { Sig } \\
\text { (2-tailed) }\end{array}$ & $\begin{array}{l}\text { Sig } \\
\text { (1-tailed) }\end{array}$ & Interpretation \\
\hline \multirow{3}{*}{ MPPA } & SA-WIN & 24.91 & 3.94 & 34 & \multirow{3}{*}{0.00} & \multirow{3}{*}{0.00} & \multirow{3}{*}{$\begin{array}{l}\bar{x}-\mathrm{MPPA}_{\mathrm{SA}-\mathrm{WIN}}> \\
\bar{x}-\mathrm{MPPA}_{\mathrm{CT}}\end{array}$} \\
\hline & \multirow{2}{*}{ CT } & \multirow{2}{*}{18.06} & \multirow{2}{*}{5.31} & \multirow{2}{*}{34} & & & \\
\hline & & & & & & & \\
\hline \multirow{3}{*}{$\begin{array}{l}\text { N-gain } \\
\text { MPPA }\end{array}$} & SA-WIN & 0.40 & 0.15 & 34 & \multirow{3}{*}{0.00} & \multirow{3}{*}{0.00} & \multirow{3}{*}{$\begin{array}{l}\overline{\boldsymbol{x}}-(\mathrm{g})-\mathrm{MPPA}_{\mathrm{SA}-\mathrm{WIN}}> \\
\overline{\boldsymbol{x}} \text {-(g)-MPPA }{ }_{\mathrm{CT}}\end{array}$} \\
\hline & CT & 0.21 & 0.09 & 34 & & & \\
\hline & & & & & & & \\
\hline
\end{tabular}

Based on Table 10, testing hypothesis of $\overline{\mathrm{x}}_{\mathrm{SA} \text {-WIN }}>\overline{\mathrm{x}}_{\mathrm{CT}}$ on student's MPPA, N-gain MPPA in entirely students SA-WIN strategy gave a better role than PMA toward student's MPPA.

The students' difficulties in solving the MPPA task were attached in Table 11 below:

Table 11

Mean Score of Each Item of MPPA of Students in the Both Teaching Approach

\begin{tabular}{lllllll}
\hline \multirow{2}{*}{ Teaching approach } & No & 1 & 2 & 3 & 4 & 5 \\
\cline { 2 - 7 } & Ideal score & 10 & 10 & 8 & 10 & 10 \\
\hline \multirow{2}{*}{ SA-WIN } & $\overline{\mathbf{x}}$ & 6.88 & 6.24 & 4.91 & 3.44 & 3.44 \\
\cline { 2 - 7 } & \% of ideal score & 68.80 & 62.40 & 61.38 & 34.40 & 34.40 \\
\hline \multirow{2}{*}{ CT } & $\overline{\mathbf{x}}$ & 5.18 & 4.47 & 3.12 & 2.35 & 3.00 \\
\cline { 2 - 7 } & \% of ideal score & 51.80 & 44.70 & 39.00 & 23.50 & 30.00 \\
\hline
\end{tabular}

Based on Table 11, students taught by SA-WIN attained medium score on three items (number 1, 2, and 3). It pointed out those students still realized a little bit difficult on MPPA tasks. Even though most students taught by conventional teaching realized difficulties on all items of MPPA. Seemingly, MPPA tasks, especially on number 4 and 5 , were difficult mathematical tasks for students.

One of the students' answers to the mathematical problem posing test shown in Figure 2 below:

There are five men and four women to form a line so that women occupy an even position. How many possibilities are that sequence? Arrange two new questions 
from the question above. Then, select one new question and finish accompanied by an explanation of the formula used!

When answering the question "How many possibilities are that sequence," students use the concept of multiplication rules by making a grid arrangement, as shown in Figure 2 below:

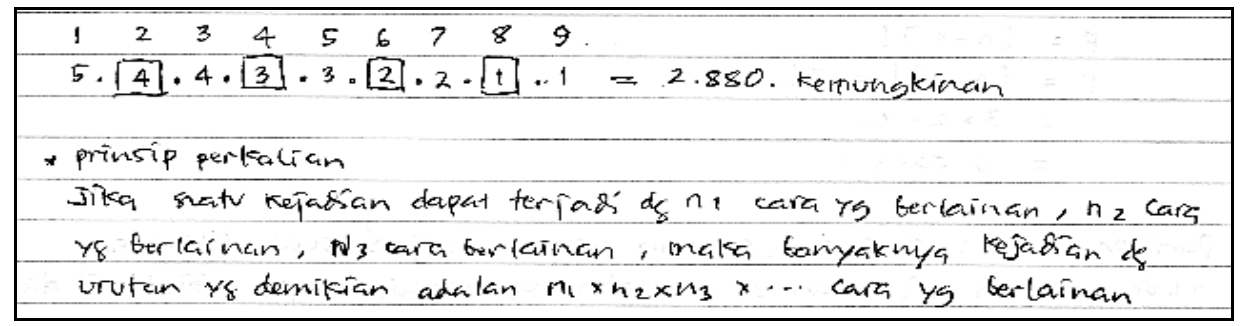

Figure 2

Students' Answer in Determining Many Possibilities

Based on Figure 2, students write numbers 1, 2, 3, 4, 5, 6, 7, 8, 9 which indicate the position of 9 people, namely 5 men and 4 women. Information on the question, even position is occupied by women. Students write position 1 there are 5 possibilities for man occupation, position 2 there are 4 possibilities for women to occupy, position 3 there are 4 possibilities for man occupation, position 4 there are 3 possibilities for women to occupy, position 5 there are 3 possibilities for man occupation, position 6 there are 2 possibilities for women to occupy, position 7 there are 2 possibilities for man occupation, position 8 there is 1 possibility for women to occupy, and position 9 there is 1 possibility for men to occupy. There are many possibilities for women to become even positions are $5 \times 4 \times 4 \times 3 \times 3 \times 2 \times 2 \times 1 \times 1=2880$. Students can solve questions. Their understanding of the principle of multiplication is if an event can occur in $n_{1}$ different ways, $n_{2}$ different ways, $n_{3}$ different ways, etc., then many events in that order are $n_{1} \times n_{2} \times n_{3} \times \ldots$ different ways.

Difficulties experienced by students occur in the command questions "Arrange two new questions from the question above". This command directs students to make questions that are still related to the problem. The students' mistakes in the new questions they compiled were not related to the previous questions. Also, students have compiled new questions correctly but do not include the solution. This condition causes the assessment of the items obtained by students to be low. New questions compiled by students are shown in Figure 3 below:

a bagaimana jika laki laki yang berada diposisi genap?
b. berapa banyole cara jika fumlah perempuan menjadi 5 orang?

Figure 3

Student Answers in Compiling Two Questions in Item Number 1

The following are rewritten the student's questions. 
a. What if a man is in an even position?

b. How many ways if the number of women becomes five people?

This problem-posing activity can develop students' thinking. According to Ulfah, Prabawanto, \& Jupri (2017), students who carry out problem-posing activities can improve their creative thinking abilities. In helping students develop new questions from existing information supported by SA-WIN learning. Students can change data but questions are the same, add data but questions are the same, change questions but data are the same, or add data and change questions(Brown \& Walter, 2005).

Figure 3 displays the two questions students asked. In question (a), students think that if a man occupies an even position, how many possibilities are that sequence? This question raised by students is due to the previous question of women who occupy an even position with a total of 4 people, while the number of men is 5 . There is a curiosity of students about the many possibilities that occur when men who are in that even position. In question (b), students change the data of women into 5 people and ask the possibility of many ways that can occur.

Based on the two questions compiled by students, they choose one of them is question (b) "How many ways if the number of women becomes five people?" The student's answers are shown in Figure 4 below:

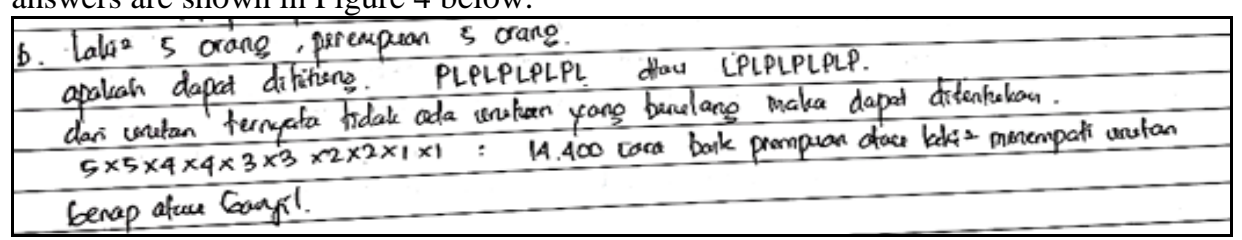

Figure 4

Student Answer Selected in Figure 3

Figure 4 shows students completing new questions by writing 5 Men (L) and 5 Women (P). Students make a line pattern of PLPLPLPLPL or LPLPLPLPLP. Based on this pattern, students state that there is no repeated sequence so that it can be determined. This student statement does not contain explicit information. Students do multiplication $5 \times 5 \times 4 \times 4 \times 3 \times 3 \times 2 \times 2 \times 1 \times 1$ then concluded that there were 14,400 ways that both women and men were even or odd.

Conformity between conclusions and new questions raised by students is inappropriate. In question (b), students do not ask men and women to occupy even or odd positions. However, students concluded that there were 14,400 ways in which women and men occupied even and odd positions. This condition shows that the ability of students to solve mathematical problems is still low. Most students have difficulty understanding problems (Putra, Putri, Fitriana, \& Andayani, 2018). In SA-WIN learning there is a "concluding" stage that can facilitate students in checking back problem-solving so that students' mistakes can be minimized. 
To find out whether there is an interaction between PMA, SA-WIN, and CT toward MPPA, an analysis is performed as in Table 12 below:

Table 12

Two Way ANOVA between PMA and SA-WIN and CT toward MPPA

\begin{tabular}{llllll}
\hline Sources & Type III Sum of Squares & df & $\begin{array}{l}\text { Mean } \\
\text { Square }\end{array}$ & F & Sig. \\
\hline Teaching Approaches & 617,660 & 1 & 617,660 & 38,994 & 0,000 \\
\hline PMA & 1513,843 & 2 & 756,922 & 47,786 & 0,000 \\
\hline $\begin{array}{l}\text { Teaching } \\
\text { Approaches*PMA }\end{array}$ & 4,675 & 2 & 2,338 & 0,148 & 0,863 \\
\hline
\end{tabular}

Based on the results of the analysis in Table 12, the study found that there was no interaction between PMA and teaching approaches (SA-WIN and CT) toward MPPA because sig. $=0.863>0.05$. These findings pointed out that SA-WIN took a better role than PMA and CT on improving MPPA. Besides that, this study also found that students proposed a positive opinion on SA-WIN. Students agree that SA-WIN makes them active in learning through observing, asking questions using what-if-not strategy, exploring, reasoning, and concluding solutions to MPPA problems.

Student's MPPA with high level have an average percentage agreed that worksheets encourage students to learn actively, identify concepts, work tenaciously, and find concepts of $84.25 \%$. Student's MPPA with medium level are getting an average percentage of $81.75 \%$ while student's MPPA with low level is $74.75 \%$. Student's MPPA with high level has an average percentage of the learning atmosphere encourages students to bravely arrange their problems and improve the self-confidence of $83.50 \%$. Student's MPPA with medium level are getting an average percentage of $79.00 \%$ while student's MPPA with low level is $74.00 \%$. Student's MPPA with high level has an average percentage of the information on worksheets easy to understand and encourages the spirit of learning of $82.50 \%$. Student's MPPA with medium level are getting an average percentage of $82.00 \%$ while student's MPPA with low level is $70.50 \%$.

Student's MPPA with high level has an average percentage of the task of conveying the results of group work provides an opportunity for students to argue and dare to express their opinions of $71.50 \%$. Student's MPPA with medium level are getting an average percentage of $72.00 \%$ while student's MPPA with low level is $63.00 \%$. Student's MPPA with high level have an average percentage the learning atmosphere makes students open to discuss with one another, fosters enthusiasm for learning, worksheets are easy to understand, practice reflective thinking, make connections between concepts learned, arrange problems, solve problems in various ways, train to draw conclusions from observations, assignments to challenge questions to work on, the information on the worksheet is easy to understand, and encourages the spirit of learning of $69.27 \%$. Student's MPPA with medium level are getting an average percentage of $68.45 \%$ while student's MPPA with low level is $62.82 \%$. 


\section{DISCUSSION}

Basically, in any teaching approach, the teacher would pose the student to some relevant mathematics problems. Without realized teacher took greater attention on obtaining student's Mathematical Problem-Solving Ability (MPSA) only and not on attaining student's Mathematical Problem-Posing Ability (MPPA). Likewise, the teacher took less attention to the quality of his compiled mathematics problem that trained to his student. Teacher rarely trains students to compile their mathematics problem. Suarsana, Lestari, \& Mertasari (2019) stated that problem-posing could improve students' creative thinking to help them solve the problem. This research was conducted to train students in compiling their questions from a problem using Scientific Approach with What-IfNot Strategy (SA-WIN).

In the pretest, it found that there was no difference in student's MPPA level in both teaching approaches and the level was at a very low. Students getting treatment with SAWIN attained MPPA scores that are better than the students taught by conventional teaching. The results of Mutholib, Sujadi, \& Subanti (2017) research was found that SA gives impact to students' progress, and by applying SA, the target of mathematics learning is acquired. Hendriana, Putra, \& Ristiana (2018) stated that SA could make students actively involved in observing problems, asking questions, trying strategies, solving problems, and concluding concepts. Smart students are involved in helping students who are less intelligent.

SA-WIN and PMA had almost the same level of role on attaining student's MPPA. Students who have a high level of PPA will have better MPPA. Those findings pointed out that level of PMA and SA-WIN conferred a more significant role than PMA on attaining improvement of MPPA. WIN strategy has a role in developing MPPA students. When using the WIN strategy, they all seek a useful way of discovering solutions to the problems by changing the scope, their assigned conditions, concerned variables, and structures of the suggested problems (Schoenfeld, 1985; Moses, Bjork, \& Goldenberg, 1990).

Students realized the difficulty in solving MPPA tasks. Students realized difficulties compile questions before, during, and after problem-solving and detailing the main problem of a non-simple mathematical problem in the question of the part. According to Herman (2007), students are not used to it, and many have difficulty in learning mathematics, which starts from problem-solving activities. They have become accustomed to hearing the teacher's description and accepting mathematics in its complete form. Putra, Herman, \& Sumarmo (2017) states that teaching materials that contain activities in the scientific approach can improve MPPA students with medium criteria.

The implication of the study is that MPPA students increase after using SA-WIN. MPPA is important for students because it can foster critical thinking skills, creative thinking, reflective thinking, and logical thinking in solving problems. Five stages in SA-WIN support the improvement of students' thinking skills. at the stage of observing a problem, students obtain information. In the stage of asking a problem, students use 
WIN strategy that gives rise to students' creative thinking in constructing old problems into new problems. In the stage of trying to solve a problem, students think critically in finding problem-solving strategies. In the reasoning stage, students think logically in determining the steps for problem-solving to make sense and be appropriate. In the concluding stage, students think reflectively in re-checking the truth of problem-solving. MPPA can develop other mathematical thinking skills. Once the importance of MPPA for students and SA-WIN has a role in improving the ability of their MPPA.

\section{CONCLUSION}

The study concludes that the Scientific Approach with What-If-Not strategy (SA-WIN) took better role than Conventional Teaching (CT) to improve students' Mathematical Problem Posing Ability (MPPA). The students' MPPA level was still at medium. The level of PMA gave an excellent role in obtaining student's MPPA level. The better the PMA level of students, the better the level of their MPPA. Most students who use conventional teaching have difficulties in solving problems in the MPPA test. Learning using SA-WIN encourages students to be active in asking questions, discussing, and solving MPP problems. Students give a positive perception of SA-WIN. There was no interaction between PMA and the teaching approach to improve the MPPA of students.

\section{RECOMMENDATION}

Mathematical problem posing skills are very important for students. To find out the concept of understanding students can be seen from the questions they ask. The results of this research recommend that the scientific approach to what-if-not strategies can improve students' mathematical problem posing abilities. PS-WIN can be used to develop students' interests in other mathematical materials, so that different test and nontest instruments are needed and are best designed. Time management in class is also needed so that learning objectives can be achieved properly.

\section{ACKNOWLEDGEMENT}

The author would like to thanks the Ministry of Research, Technology, and Higher Education (Kemenristek Dikti), Institut Keguruan dan Ilmu Pendidikan Siliwangi, and Universitas Pendidikan Indonesia. We are grateful for the support for this research.

\section{REFERENCES}

Anglin, L., \& Anglin, K. (2008). Business education, teaching, and the millennials. In The Academy of Business Disciplines.

Arikunto, S. (2013). Prosedur Penelitian: Suatu Pendekatan Praktik. Jakarta: Rineka Cipta.

Bonotto, C. (2013). Artifacts as sources for problem-posing activities. Educational Studies in Mathematics, 83, 37-55.

Branca, N. A. (1980). Problem solving a goal, process, and basic skill. In S. Krulik, \& R. E. Reys (Eds.), Problem-solving in school mathematics (pp. 3-8). Reston, VA: National Council of Teachers of Mathematics. 
Brown, S. I., \& Walter, M. I. (2005). The art of problem posing. London: Lawrence Erlbaum Associates.

Creswell, J. w. (2009). Research design: Qualitative, quantitative, and mix methods approach. Newbury Park: Sage Publications.

Ellerton, N. F., \& Clarkson, P. C. (1996). Language factors in mathematics teaching and learning. In A. I. Bishop (Ed.), International handbook of mathematics education (pp. 987-1033). Alphen Aaden Rijn: Kluwer Academic Publishers.

Hake, R. R. (1999). Analyzing change/gain scores. American Education Research Association, (August 2001), 1-61.

Hendriana, H., Putra, H., \& Ristiana, M. (2018). Scientific approach in developing mathematical analogy and communication ability of junior high school students in remote areas. In International Conference on Mathematics and Science Education (pp. 597-601). Bandung: Universitas Pendidikan Indonesia.

Hendriana, H., \& Sumarmo, U. (2014). Penilaian pembelajaran matematika. PT Refika Aditama. Bandung: Refika Aditama.

Herman, T. (2007). Pembelajaran berbasis masalah untuk meningkatkan kemampuan penalaran matematis siswa SMP. Cakrawala Pendidikan, 26(1), 41-62.

Hosnan. (2014). Pendekatan saintifik dan kontekstual dalam pembelajaran abad 21. Bogor: Ghalia Indonesia.

McCarthy, J. P., \& Anderson, L. (2004). Active learning techniques versus traditional teaching styles: Two experiments from history and political science. Innovative Higher Education, 24(4), 279-294. https://doi.org/10.1023/b:ihie.0000047415.48495.05.

Moses, B., Bjork, E., \& Goldenberg, E. P. (1990). Beyond problem-solving: Problem posing. In S. I. Brown, \& M. I. Walter (Eds.), Teaching and learning mathematics in the 1990s: 1990 Yearbook (pp. 82-91). Hillsdale, NJ: Lawrence Erlbaum Associates, Publisher.

Mutholib, A. A., Sujadi, I., \& Subanti, S. (2017). Mathematics teachers' beliefs about the scientific approach (SA) and implementation in mathematics learning. In AIP Conference Proceedings, 1868, 050036.1-050036.5. https://doi.org/10.1063/1.4995163.

Polya, G. (1985). How to solve it. New Jersey: Princeton University Press.

Putra, H. D. (2017). Pengembangan Instrumen Untuk Meningkatkan Kemampuan Mathematical Problem Posing Siswa SMA. Euclid, 4(1), 636-645.

Putra, H. D., Herman, T., \& Sumarmo, U. (2017). Development of student worksheets to improve the ability of mathematical problem posing. International Journal on Emerging Mathematics Education, 1(1), 1-10. https://doi.org/http://dx.doi.org/10.12928/ijeme.v1i1.5507.

Putra, H. D., Putri, W. A. S., Fitriana, U., \& Andayani, F. (2018). Kemampuan 
Pemecahan masalah matematis dan self-confidence siswa. Supremum Journal of Mathematics Education, 2(1), 60-70.

Schoenfeld, A. (1985). Mathematical problem-solving. New York: Academic Press.

Silver, E. A. (2013). Problem-posing research in mathematics education: Looking back, looking around, and looking ahead. Educational Studies in Mathematics, 83(1), 157162. https://doi.org/10.1007/s10649-013-9477-3.

Singer, F. M., Ellerton, N. F., \& Cai, J. (2013). Problem-posing research in mathematics education: Looking back, looking around, and looking ahead. Educational Studies in Mathematics, 87(1), 1-7.

Suarsana, I M; Lestari, I A P D; Mertasari, N. M. S. (2019). The effect of online problem posing on students' problem-solving ability in mathematics. International Journal of Instruction, 12(1), 809-820.

Sudarwan, D. (2013). Menjadi penulis kualitatif. Bandung: Pustaka Setia Sudiarta.

Ulfah, U., Prabawanto, S., \& Jupri, A. (2017). Students' mathematical creative thinking through problem posing learning. Journal of Physics: Conference Series, 895, 012097. https://doi.org/10.1088/1742-6596/895/1/012097.

Vinet, L., \& Zhedanov, A. (2010). A "missing" family of classical orthogonal polynomials. Journal of Physics A: Mathematical and Theoretical, 44(8), 085201. https://doi.org/10.1088/1751-8113/44/8/085201 